\title{
PENERAPAN MODEL POLYA BERORIENTASI MASALAH SOAL CERITA KONTEKSTUAL UNTUK MENINGKATKAN KEMAMPUAN PEMECAHAN MASALAH MATEMATIKA SISWA KELAS V SD NEGERI 7 BUGBUG
}

\author{
Putu Suarniti Noviantari \\ Program Studi Pendidikan Matematika \\ Universitas Mahasaraswati Denpasar
}

\begin{abstract}
ABSTRAK
Penelitian ini bertujuan untuk (1) meningkatkan kemampuan pemecahan masalah matematika siswa kelas V SD Negeri 7 Bugbug tahun ajaran 2017/2018 dan (2) mengetahui sikap siswa terhadap matematika setelah pembelajaran diterapkan. Jenis penelitian ini adalah penelitian tindakan kelas yang terdiri dari tiga siklus. Setiap siklus terdiri dari tahap perencanaan, pelaksanaan tindakan, observasi/evaluasi, dan refleksi. Subjek penelitian ini adalah siswa kelas V SD Negeri 7 Bugbug tahun ajaran 2017/2018 sebanyak 39 orang. Data tentang kemampuan pemecahan masalah matematika siswa dikumpulkan melalui tes berbentuk uraian dan data tentang sikap siswa dikumpulkan melalui angket. Data-data yang dikumpulkan dianalisis menggunakan analisis deskriptif. Hasil penelitian menunjukkan bahwa terjadi peningkatan kemampuan pemecahan masalah matematika siswa melalui penerapan model Polya berorientasi masalah soal cerita kontekstual. Kemampuan pemecahan masalah matematika melalui penerapan model Polya berorientasi masalah soal cerita kontekstual mengalami peningkatan sebesar 36,07. Sikap siswa terhadap matematika setelah penerapan model Polya berorientasi masalah soal cerita kontekstual tergolong positif dengan rata-rata skor sebesar 38,17.
\end{abstract}

Kata kunci: model Polya, soal cerita kontekstual, kemampuan pemecahan masalah

\section{ABSTRACT}

This research aimed at (1) improving the fifth grade students' math problem solving skill in SD Negeri 7 Bugbug in academic year 2017/2018 and (2) investigating the students' attitude towards mathematics after the teaching learning process applied.This resarch is a clasroom action research consisted of 3 cycles. Each cycle involved plan, action, observation/evaluation, and reflection stages. The subject of the study was the fifth grade students in SD Negeri 7 Bugbug in academic year 2017/2018 with 39 number of students. The data about the students' math problem solving skill were collected by administering essay test and the data about the students' attitude were gathered by using questionnaire. The data were anaylzed by means of descriptive analysis. The research findings showed that there was an improvement on the students' math problem solving skill through the application of Polya Model orienting Contextual Story question problem. The skill of math problem solving was increased 36.07 poin. The students' attitude towards mathematics after implementing Polya Model orienting Contextual Story question problem was categorized positive with the average score was 38.17 .

Keywords: Polya Model, contextual story question, problem solving skill. 


\section{PENDAHULUAN}

Pendidikan memegang peran yang sangat penting dalam proses peningkatan kualitas sumber daya manusia. Upaya yang dilakukan pemerintah untuk meningkatkan kualitas pendidikan adalah dengan melakukan perbaharuan dalam Kurikulum Tingkat Satuan Pendidikan (KTSP) menjadi Kurikulum Tahun 2013. Kualitas pendidikan matematika juga diharapkan meningkat dengan adanya kurikulum yang baru. Matematika merupakan ilmu paling dasar yang menopang ilmu-ilmu yang lain sehingga wajib dikuasai oleh siswa. Pembelajaran matematika di sekolah memiliki empat tujuan utama di mana salah satunya memuat pengembangan kemampuan pemecahan masalah. Kemampuan ini dapat dikembangkan dengan melatih siswa menyelesaikan masalah-masalah matematika, tidak hanya terkait dengan solusi akhir melainkan juga proses dalam penemuan solusi tersebut. Berdasarkan fakta di lapangan, pemecahan masalah matematika masih dianggap sulit khususnya di jenjang sekolah dasar. Kelemahan pemecahan masalah bagi siswa SD ditunjukkan dengan rendahnya kemampuan siswa dalam menyelesaikan masalah soal cerita kontekstual. Ini disebabkan pembelajaran masih mengarah pada pemberian soal cerita yang tidak kontekstual.

Rendahnya kemampuan siswa menyelesaikan masalah soal cerita kontekstual juga dialami oleh siswa kelas V SD Negeri 7 Bugbug. Berdasarkan hasil observasi diperoleh gambaran bahwa dalam memecahkan masalah siswa selalu terpaku pada contoh-contoh penyelesaian yang diberikan oleh guru. Siswa juga belum mampu membuat rencana penyelesaian dan menyelesaikan rencana tersebut dengan baik. Siswa juga jarang sekali melihat kembali pekerjaan yang telah dilakukan. Rendahnya kemampuan pemecahan masalah matematika siswa kelas V SD Negeri 7 Bugbug dapat dilihat dari contoh hasil pemecahan masalah oleh siswa yang disajikan dalam tabel berikut.

\section{Tabel 1 Hasil Tes Pemecahan Masalah Siswa}

\begin{tabular}{lccc}
\hline \multicolumn{1}{c}{ Pertanyaan } & Langkah Model Polya & $\begin{array}{c}\text { Banyaknya siswa } \\
\text { menjawab benar }\end{array}$ & Prosentase \\
\hline $\begin{array}{l}\text { Seekor induk ayam } \\
\text { mempunyai 16 anak ayam. }\end{array}$ & $\begin{array}{l}\text { - Memahami masalah } \\
\text { - Membuat rencana }\end{array}$ & 18 & $46,15 \%$ \\
$\begin{array}{l}\text { Yang berwarna putih ada 9 } \\
\text { ekor dan sisanya berwarna }\end{array}$ & $\begin{array}{c}\text { - Melesaian masalah } \\
\text { penyelesaian masalah }\end{array}$ & 10 & $25,64 \%$ \\
$\begin{array}{l}\text { hitam. Berapakah } \\
\text { perbandingan banyak anak } \\
\text { ayam yang berwarna putih } \\
\text { dan hitam? }\end{array}$ & \begin{tabular}{c} 
- Melihat kembali \\
\hline
\end{tabular} & 6 & $15,38 \%$ \\
\hline
\end{tabular}

Dari hasil di atas dapat dilihat bahwa siswa yang mampu menjawab dengan tepat untuk masing-masing langkah kurang dari 50\%. Ini menunjukkan bahwa kemampuan pemecahan masalah matematika siswa masih kurang. Berdasarkan hasil wawancara pada tanggal 31 Maret 2016 dengan seorang guru matematika di kelas tersebut mengungkapkan bahwa guru belum sepenuhnya menerapkan langkahlangkah pemecahan masalah seperti yang diberikan oleh Polya khususnya pada langkah melihat kembali. Sementara, berdasarkan hasil wawancara dengan siswa SD Negeri 7 Bugbug diperoleh informasi bahwa siswa masih kesulitan 
menyelesaikan soal pemecahan masalah soal cerita kontekstual.

Penyebab lain rendahnya prestasi belajar matematika siswa, yaitu siswa kurang senang saat belajar matematika dan siswa jarang diberikan kesempatan untuk menyampaikan ide dan gagasannya dalam pembelajaran. Menyikapi hal ini, ada beberapa alternatif pembelajaran yang dapat meningkatkan kemampuan pemecahan masalah matematika antara lain model pembelajaran akselerasi (accelerated learning), problem posing, dan model Polya. Diantara ketiga alternatif tersebut, model Polya lebih cocok diterapkan di sekolah dasar. Dipilihnya model Polya mengingat model ini memiliki dampak instruksional berupa dimilikinya pemahaman masalah dan dampak pengiring berupa kemampuan berpikir, memecahkan masalah, dan kemampuan intelektual serta menjadi siswa yang mandiri (Sudiana, 2008). Tahapan-tahapan dari model Polya meliputi (1) memahami masalah, (2) merencanakan penyelesaian masalah, (3) melaksanakan rencana penyelesaikan masalah dan (4) melihat kembali. Penyelesaian soal secara sistematis akan memudahkan siswa dalam memecahkan masalah soal cerita kontekstual. Kemudahan-kemudahan tersebut akan memotivasi kemampuan siswa dalam menyelesaikan masalah soal cerita kontekstual.

Berdasarkan uraian tersebut, penulis memandang perlu megadakan penelitian tentang "Penerapan Model Polya Berorientasi Masalah Soal Cerita Kontekstual untuk Meningkatkan Kemampuan Pemecahan Masalah Matematika Siswa Kelas V SD Negeri 7 Bugbug". Berdasarkan pemaparan tersebut, maka permasalahan yang dibahas dalam penelitian ini adalah seberapa besar peningkatan kemampuan pemecahan masalah matematika siswa kelas V SD Negeri 7 Bugbug melalui penerapan model Polya berorientasi masalah soal cerita kontekstual dan bagaimana sikap siswa kelas V SD Negeri 7 Bugbug terhadap matematika setelah penerapan model Polya berorientasi masalah soal cerita kontekstual?

\section{METODE PENELITIAN}

Penelitian ini termasuk jenis penelitian tindakan kelas (PTK) atau classroom action research yang dilaksanakan dalam tiga siklus. Masingmasing siklus terdiri atas empat tahapan yaitu tahap perencanaan tindakan, pelaksanaan tindakan, observasi dan evaluasi, serta refleksi. Penelitian tindakan kelas ini dilaksanakan di kelas $\mathrm{V}$ pada semester ganjil 2017/2018. Siswa ini dipilih sebagai subjek penelitian karena di kelas V ditemukan permasalahanpermasalahan seperti yang terurai pada pendahuluan. Objek dalam penelitian tindakan kelas ini adalah (1) kemampuan pemecahan masalah matematika melalui penerapan model Polya berorientasi masalah soal cerita kontekstual dan (2) sikap siswa terhadap matematika setelah penerapan model Polya berorientasi masalah soal cerita kontekstual.

Prosedur suatu penelitian tindakan kelas, dalam hal ini dilakukan 2 kegiatan, yaitu refleksi awal dan pelaksanaan penelitian. Secara mendetail mengenai masing-masing kegiatan tersebut akan diuraikan masing-masing sebagai berikut. 1) Refleksi awal. Kegiatan refleksi awal ini meliputi wawancara, dan observasi dengan guru matematika kelas V SD Negeri 7 Bugbug. Observasi dan wawancara ini dilakukan untuk 
memperoleh gambaran yang lebih jelas mengenai masalah yang dihadapi di sekolah berangkutan terkait dengan pembelajaran matematika. Berdasarkan hasil wawancara dan observasi kelas selanjutnya diperoleh kesepakatan untuk memecahkan masalah yang dipaparkan dalam latar belakang (rendahnya kemampuan pemecahan masalah) dengan menerapkan model Polya berorientasi masalah soal cerita kontekstual. 2) Pelaksanaan Penelitian. Penelitian ini dilakukan suatu tindakan yang dilaksanakan dalam 3 siklus. Adapun tindakan yang dilaksanakan pada tiap siklus adalah 4 kali pertemuan, 3 kali pertemuan untuk pelaksanaan tindakan dan 1 kali pertemuan untuk pelaksanaan tes. Materi yang dibahas dalam siklus ini yaitu menggambar bangun datar (segitiga, persegi, persegi panjang, lingkaran, belah ketupat, dan layang-layang) dan menggambar bangun ruang (prisma tegak segiempat dan limas). Dalam siklus ini dilakukan beberapa kegiatan sebagai berikut.

\section{Tabel 2 Siklus Penelitian}

Siklus I Perencanaan tindakan $\quad$ Penyamaan persepsi dengan guru mata pelajaran
matematika V SD Negeri 7 Bugbug mengenai model Polya.

* Pembuatan rencana pembelajaran dan LKS yang didasarkan atas model Polya. Rencana pembelajaran dan LKS ini dikonsultasikan dengan guru di sekolah dan dosen pembimbing.

* Menyiapkan instrumen penelitian yang berupa tes berbentuk uraian

Pelaksanaan tindakan Pada tahap pelaksanaan tindakan ini, guru melaksanakan pembelajaran berdasarkan rencana pembelajaran yang telah disusun pada tahap perencanaan yaitu rencana pembelajaran yang mengacu pada penerapan model Polya. Pada kesempatan ini penulis melakukan observasi kelas dengan berlandaskan pada instrumen yang telah disusun pada tahap perencanaan.Dalam melaksanakan pembelajaran di kelas guru juga berpegang pada model pembelajaran yang telah disepakati.

Observasi dan Evaluasi Selama pelaksanaan tindakan, peneliti mengadakan observasi untuk memperoleh gambaran mengenai kekurangan-kekurangan yang terjadi di dalam proses pembelajaran. Evaluasi kemampuan pemecahan masalah matematika siswa dilakukan dengan memberikan tes uraian pada akhir siklus. Atas dasar observasi kelas yang dilakukan selama kegiatan siklus I peneliti bersama guru melakukan evaluasi secara umum untuk mengetahui seberapa besar keberhasilan tindakan yang dilakukan pada siklus tersebut.

Refleksi Pada akhir siklus I ini peneliti bersama guru melakukan refleksi terhadap hasil yang dicapai selama ini dengan mengkaji kendala atau kekurangan dari tindakan yang telah dilaksanakan. Berdasarkan hasil refleksi ini peneliti bersama guru mencoba merumuskan tindakan baru sebagai penyempurnaan yang akan dipakai pada tindakan dalam siklus II.

Siklus II Tahapan-tahapan pada siklus II dan III pada prinsipnya sama dengan tahapan-tahapan 


\begin{tabular}{ll}
\hline dan III & pada siklus I yaitu terdiri dari tahap perencanaan, pelaksanaan tindakan, observasi dan \\
evaluasi, serta refleksi akhir siklus. Siklus II dilaksanakan jika kriteria keberhasilan \\
yang ditetapkan belum tercapai pada siklus I, demikian seterusnya. Hanya saja kegiatan \\
pada siklus ini didasarkan pada permasalahan-permasalahan yang ditemui pada refleksi \\
siklus I dan merupakan perbaikan dari tindakan siklus I. Siklus III dilaksanakan jika \\
kriteria keberhasilan yang ditetapkan belum tercapai pada siklus II. Langkah-langkah \\
tindakan pada siklus II dan siklus III dapat berubah sesuai dengan hasil refleksi. \\
Perubahan langkah-langkah dilakukan tanpa mengubah substansi tindakan penelitian \\
yang direncanakan.
\end{tabular}

Data yang diperlukan adalah data tentang kemampuan pemecahan masalah matematika siswa serta sikap siswa terhadap matematika setelah penerapan model Polya berorientasi masalah soal cerita kontekstual. Data tentang kemampuan pemecahan masalah matematika siswa diperoleh dari hasil pemberian tes uraian sedangkan data siswa terhadap matematika setelah penerapan model Polya berorientasi masalah soal cerita kontekstual diperoleh dari hasil pemberian angket.

Data kemampuan kemampuan pemecahan masalah matematika siswa dianalisis berdasarkan rata-rata skor $(\bar{X})$, mean ideal (MI), dan standar deviasi ideal (SDI). Soal yang diberikan kepada siswa sebanyak 5 item soal uraian sehingga skor maksimum yang mungkin diperoleh siswa adalah 60, dan skor minimum adalah 0 . Berdasarkan skor yang diperoleh dalam pengumpulan data, maka akan diperoleh data-datal sebagai berikut.

$$
\text { Mean Ideal }\left(M_{i}\right)=\frac{1}{2}(\text { Skor }
$$

maksimum + Skor minimum $)=30$

Standar Deviasi Ideal $\left(S D_{i}\right)=$ $\frac{1}{6}($ Skor maksimum + Skor minimum $)=$ 10
Data mengenai kemampuan pemecahan masalah matematika siswa ditentukan dengan kriteria:

$$
\begin{aligned}
& \overline{\mathbf{X}} \geq 45 \rightarrow \text { Sangat baik } \\
& 35 \leq \overline{\mathrm{X}}<45 \rightarrow \text { Baik } \\
& 25 \leq \overline{\mathrm{X}}<35 \rightarrow \text { Cukup } \\
& 15 \leq \overline{\mathrm{X}}<25 \rightarrow \text { Kurang } \\
& \overline{\mathrm{X}}<15 \quad \rightarrow \text { Sangat Kurang } \\
& \text { (dimodifikasi dari Nurkancana \& } \\
& \quad \text { Sunartana, 1986) }
\end{aligned}
$$

Dengan $\overline{\mathbf{X}}$ adalah rata-rata skor Selanjutnya, rata-rata ini dinyatakan dalam skala seratus. Dalam penelitian ini diharapkan kemampuan pemecahan masalah matematika siswa minimal mencapai kriteria baik. 


\section{HASIL DAN PEMBAHASAN}

\section{Kemampuan Siswa dalam Pemecahan}

Masalah

Tabel 3 Kemampuan Pemecahan Masalah Matematika Siswa pada Refleksi Awal, Siklus I, Siklus II, dan Siklus III

\begin{tabular}{lcc} 
Tahapan & Jumlah Skor & Rata-Rata Skor \\
\hline Refleksi Awal & 856 & 36,58 \\
\hline Siklus I & 1176 & 50,25 \\
\hline Siklus II & 1514 & 64,70 \\
\hline Siklus III & 1700 & 72,65 \\
\hline
\end{tabular}

\section{Sikap Siswa}

Data mengenai sikap siswa terhadap matematika setelah pembelajaran yang diterapkan dikumpulkan di akhir siklus III dengan menggunakan angket sikap. Berdasarkan data tersebut diperoleh ratarata skor sikap siswa sebesar 38,17. Jika dibandingkan dengan kriteria yang telah ditetapkan, maka sikap siswa terhadap model pembelajaran yang diterapkan tergolong positif.

Berdasarkan analisis data dapat dilihat bahwa kemampuan pemecahan masalah matematika siswa pada siklus I belum memenuhi kriteria yang ditetapkan karena tergolong dalam kategori cukup. Rata-rata skor kemampuan pemecahan masalah matematika siswa sebelum tindakan yaitu sebesar 21,95 dan berada dalam kriteria kurang baik. Setelah dinyatakan dalam skala seratus, rata-rata kemampuan pemecahan masalah berubah menjadi 36,58 .

Pada siklus I, rata-rata skor kemampuan pemecahan masalah matematika setelah dinyatakan dalam skala seratus adalah 50,25. Rata-rata skor kemampuan pemecahan masalah matematika siswa pada siklus I belum mencapai indikator keberhasilan yang diharapkan adanya beberapa kekurangan sebagai berikut. Pertama, siswa merasa kesulitan memecahkan masalah dalam bentuk soal. Kedua, dalam diskusi kelompok masih terlihat ada siswa yang enggan untuk berdiskusi dengan teman. Ketiga, sebagian besar siswa belum terbiasa mempertimbangkan rencana/strategi dengan menyajikan langkah-langkah sebelum menyelesaikan masalah. Untuk mengatasi kekurangankekurangan yang ditemui pada siklus I, peneliti bersama dengan guru mendiskusikan perbaikan tindakan untuk selanjutnya diterapkan pada siklus II.

Perbaikan tindakan yang dilakukan pada siklus II yaitu sebagai berikut. Pertama, guru/praktikan memberikan strategi penyelesaian masalah disertai langkah -langkah yang harus dilengkapi siswa. Kedua, guru lebih aktif mendatangi setiap kelompok sesering mungkin untuk memberikan arahan-arahan/bimbingan, khususnya pada langkah-langkah model Polya yang belum dipahami. Ketiga, guru membimbing tiap kelompok dalam memeriksa hasil dan cara lain dalam menyelesaikan masalah.

Perbaikan tindakan yang dilaksanakan pada siklus II mengakibatkan adanya peningkatan kemampuan pemecahan masalah matematika siswa. Pada siklus II, rata-rata skor kemampuan pemecahan masalah matematika siswa 
mengalami peningkatan menjadi menjadi 64,70. Dilihat dari rata-rata tiap langkah model Polya, belum semua termasuk dalam kategori "baik". Hal tersebut disebabkan oleh beberapa kendala sebagai berikut. Pertama, masih ada siswa yang belum bisa memaparkan langkah-langkah dalam menyelesaikan masalah. Kedua, siswa belum memeriksa proses mendapatkan jawaban secara keseluruhan. Ketiga, waktu yang diberikan lebih banyak difokuskan untuk langkah I, II, dan III sehingga pada langkah ke IV kekurangan waktu. Untuk mengatasi kekurangan-kekurangan yang ditemui pada siklus II, peneliti bersama dengan guru mendiskusikan perbaikan tindakan yang akan diterapkan pada siklus II yaitu sebagai berikut. Pertama, guru melatih siswa agar dapat membagi waktu untuk tiap langkah pemecahan soal cerita kontekstual. Kedua, guru mengarahkan siswa pada hal-hal yang perlu diperiksa kembali setelah memperoleh hasil. Ketiga, siswa diminta untuk memahami kembali beberapa strategi yang termuat dalam tahapan Polya yang kedua pada pembelajaran sebelumnya. Perbaikan tindakan ini mengakibatkan adanya peningkatan kemampuan pemecahan masalah matematika siswa

Rata-rata skor kemampuan pemecahan masalah matematika siswa pada siklus III mengalami peningkatan menjadi menjadi 72,65. Rata-rata skor kemampuan pemecahan masalah matematika untuk indikator I (memahami masalah) secara kualitatif mencapai kategori "sangat baik", sedangkan untuk indikator II, III dan IV (membuat rencana, melaksanakan rencana dan memeriksa kembali) mencapai kategori "baik". Secara umum suasana belajar sudah terlihat kondusif. Berdasarkan hasil yang diperoleh pada siklus III terlihat bahwa kemampuan pemecahan masalah matematika siswa telah memenuhi kategori yang ditetapkan. Rata-rata skor pada siklus III lebih tinggi dibandingkan pada siklus II. Dilihat secara umum kemampuan pemecahan masalah matematika melalui Model Polya berorientasi masalah soal cerita kontekstual mengalami peningkatan sebesar 36,07 dari 36,58 menjadi 72,65.

Rata-rata sikap siswa terhadap matematika setelah penerapan Model Polya berorientasi masalah soal cerita kontekstual sebesar 38,17. Berdasarkan kriteria penggolongan sikap siswa secara umum tergolong positif.

\section{PENUTUP}

\section{Simpulan}

Berdasarkan hasil analisis data dan pembahasan hasil penelitian, diperoleh suatu simpulan sebagai berikut. 1) Kemampuan pemecahan masalah matematika melalui penerapan model Polya berorientasi masalah soal cerita kontekstual mengalami peningkatan sebesar 36,07 dari 36,58 menjadi 72,65. Sebelum diberikan tindakan, rata-rata skor kemampuan pemecahan masalah matematika siswa pada refleksi awal sebesar 36,58. Setelah diberikan tindakan pada siklus I, rata-rata skor kemampuan pemecahan masalah matematika siswa mengalami peningkatan sebesar 13,67 dari 36,58 pada refleksi awal menjadi 50,25 pada siklus I. Setelah diberikan tindakan pada siklus II, rata-rata skor kemampuan pemecahan masalah matematika siswa mengalami peningkatan sebesar 14,45 dari 50,25 pada siklus I menjadi 64,70 pada siklus II. Selanjutnya, pemberian tindakan pada siklus III mengakibatkan rata-rata skor kemampuan pemecahan masalah matematika siswa mengalami peningkatan sebesar 7,95 dari 64,70 pada siklus II 
menjadi 72,65 pada siklus III. 2) Setelah penerapan model Polya berorientasi masalah soal cerita kontekstual sikap siswa kelas V SD Negeri 7 Bugbug terhadap matematika adalah positif.

\section{Saran}

Hasil penelitian diharapkan dapat dijadikan masukan oleh guru maupun pembaca untuk dapat menerapkan model Polya berorientasi masalah soal cerita kontekstual dapat dijadikan sebagai alternatif dalam mengatasi masalah rendahnya kemampuan pemecahan masalah matematika siswa agar dapat lebih mengaktifkan siswa dalam pembelajaran dan melatih kerja sama siswa dalam berdiskusi sehingga diskusi menjadi lebih hidup.

\section{DAFTAR PUSTAKA}

Abidin, Z. (1989). Studi tentang Prestasi Siswa Kelas VI SD Negeri Kodya Banda Aceh dalam Menyelesaikan Soal Hitungan dan Soal Cerita. Tesis (tidak diterbitkan). Malang: PPS IKIP Malang

Arikunto, S. (2002). Dasar-dasar Evaluasi Pendidikan. Edisi Revisi. Jakarta: Bumi Aksara.

Depdiknas. (2006). Peraturan Pemerintah RI No. 19 Tahun 2006 tentang Standar Nasional Pendidikan. Jakarta : Cemerlang

Hawa, S. (1999). Pembelajaran Soal Cerita dan Model Polya pada kelas II SD. Tesis (tidak diterbitkan). Malang: PPS IKIP Malang

Hudojo. H. (1998). Mengajar Belajar Matematika. Jakarta: Depdikbud, Dirjen Dikti.
(2003). Pengembangan Kurikulum dan Pembelajaran Matematika. Edisi Revisi. Malang: Universitas Negeri Malang.

Meier, D. (2000). The Accelerated Leraning Handbook. Bandung: Kafia.

Nasution, Moh. (1994). Psikologi Pendidikan. Jakarta : Depdikbud

Nurhadi \& Senduk, A G. (2003). Pembelajaran Kontekstual dan Penerapannya dalam KBK. Malang : Universitas Negeri Malang.

Nurkancana, W. dan Sunartana, P. P. N. (1986). Evaluasi Pendidikan. Surabaya: Usaha Nasional.

Soejono. (1983). Diagnosis Kesulitan Belajar dan Pengajaran Remidia. Jakarta: Dirjen Dikti P2LPTK

Sudarmanto. (2002). Pembelajaran Program Linier melalui Pemecahan Masalah Model Polya pada Siswa Kelas II LAB IKIP N Singaraja. Tesis (tidak diterbitkan). Universitas Negeri Malang

Sudiana, I W. (2004). Pembelajaran Soal Cerita dengan Pendekatan Pemecahan Masalah Model Polya untuk Meningkatkan Prestasi Belajar Siswa Kelas II SD Sumbersari 3 Kota Malang. Tesis (tidak diterbitkan). Universitas Negeri Malang.

Sudiarta, I G. P. dkk. 2005. Pengembangan dan Implementasi Pembelajaran Matematika pada Pemecahan Masalah Kontekstual OpenEnded (Contextual Open - 
Ended Problem Solving) untuk Siswa SD di Propinsi Bali. Laporan Penelitian (tidak diterbitkan). Jurusan Pendidikan Matematika, IKIP Negeri Singaraja

Sudjana. (1992). Metode Statistika. Bandung. Tarsito

Suherman, E. (1993). Evaluasi Proses dan Hasil Belajar Matematika. Jakarta: Depdikbud.

.(2003). Strategi Pembelajaran Matematika Kontemporer. Bandung: Universitas Pendidikan Indonesia.

Suparno, P. (1997). Filafat Konstruktivisme dalam Pembelajaran. Yogyakarta: Kanisius.

Tobin, Tippins, \& Gallard. 1994. Dasardasar Proses Belajar Mengajar. Bandung: Sinar Baru Algesido.

Walgito, B. 1988. Pengantar Psikologi Umum. Yogyakarta: ANDI 